\title{
HUBUNGAN ANTARA KARAKTERISTIK DAN KADAR HB IBU HAMIL TRIMESTER III DI PUSKESMAS JAGIR SURABAYA
}

\author{
Nur Masruroh ${ }^{1}$, Gilang Nugraha ${ }^{2}$ \\ ${ }^{1}$ Fakultas Keperawatan dan Kebidanan Universitas Nahdlatul Ulama Surabaya, Jl Smea No. 57 \\ Surabaya \\ Email : masruroh@unusa.ac.id \\ ${ }^{2}$ Fakultas Kesehatan Universitas Nahdlatul Ulama Surabaya, JL Jemursari No. 51-57 Surabaya \\ Email : gilang@unusa.ac.id
}

Submitted : 02-04-2020, Reviewer:07-04-2020, Accepted: 007-04-2020

\begin{abstract}
Abstrak
Nilai normal $\mathrm{Hb}$ ditentukan dari kadar $\mathrm{Hb}$ itu sendiri. Kadar $\mathrm{Hb}$ ibu hamil terjadi jika produksi sel darah merah meningkat, nilai normal hemoglobin (12 sampai $16 \mathrm{gr} / \mathrm{dl}$ ) dan nilai normal hematokrit (37\% sampai 47\%) menurun secara mencolok. Anemia dalam kehamilan adalah kondisi ibu dengan kadar hemoglobin $(\mathrm{Hb})<11 \mathrm{gr} \%$ pada trimester I dan III sedangkan pada trimester II kadar hemoglobin < $10,5 \mathrm{gr} \%$.

Penelitian ini bertujuan untuk mengetahui hubungan antara karakteristik dan kadar $\mathrm{Hb}$ ibu hamil trimester III. Penelitian dilakukan pada bulan Maret-Mei 2019 di Puskesmas Jagir Surabaya. Metode penelitian yang digunakan adalah cross sectional dan pengambilan sampel dengan simple random sampling sebanyak 30 responden ibu hamil trimester III yang berkunjung.

Hasil penelitian menunjukkan bahwa lebih dari setengah $(56,7 \%)$ memiliki kadar $\mathrm{Hb}>11 \mathrm{~g} \%$ dan hampir setengah (43,3\% responden yang memiliki kadar $\mathrm{Hb} \leq 11 \mathrm{~g} \%$. Hasil analisis bivariat menggunakan chi square dengan $\mathrm{p}$ value $<0,05$ mendapatkan hasil adanya hubungan antara usia dan kadar $\mathrm{Hb}$ ibu hamil trimester III yaitu 0,001, terdapat hubungan antara paritas dan kadar $\mathrm{Hb}$ ibu hamil yaitu 0,003 , tidak terdapat hubungan antara pendidikan dan kadar $\mathrm{Hb}$ ibu hamil trimester III yaitu 0,11 serta tidak ada hubungan antara pekerjaan dan kadar $\mathrm{Hb}$ ibu hamil trimester III yaitu 0,72 .

Disarankan kepada petugas untuk memberikan pendidikan kesehatan pada ibu hamil untuk meningkatkan pengetahuan ibu hamil tentang bahaya anemia dalam kehamilan dan pentingnya mengkonsumsi tablet fe dan makanan yang mengandung zat besi.
\end{abstract}

Kata kunci : karakteristik, ibu, hamil, kadar $\mathrm{Hb}$

\section{Abstrack}

The normal $\mathrm{Hb}$ value is determined from the Hb level itself. Hb levels in pregnant women occur if the production of red blood cells increases, the normal value of hemoglobin (12 to $16 \mathrm{gr} / \mathrm{dl})$ and the normal value of hematocrit (37\% to 47\%) decrease significantly. Anemia in pregnancy is a condition of the mother with a hemoglobin level $(\mathrm{Hb})<11 \mathrm{gr} \%$ in the first and third trimesters while in the second trimester hemoglobin level $<10.5 \mathrm{gr} \%$.

This study aims to determine the relationship between characteristics and hemoglobin levels of third trimester pregnant women. The study was conducted in March-May 2019 at the Jagir Public Health Center in Surabaya. The research method used was cross sectional and simple random sampling as many as 30 respondents who visited third trimester pregnant women.

The results showed that more than half (56.7\%) had $\mathrm{Hb}$ levels> $11 \mathrm{~g} \%$ and almost half $(43.3 \%$ of respondents had Hb levels $<11 \mathrm{~g} \%$. The results of bivariate analysis using chi square with $p$ value $<0.05$ get the results of the relationship between age and $\mathrm{Hb}$ levels of third trimester pregnant women is 0.001, there is a relationship between parity and Hb levels of pregnant women is 0.003 , there is no relationship between education and $\mathrm{Hb}$ levels of third trimester pregnant women is 0.11 and there is no relationship between work and Hb levels for third trimester pregnant women are 0.72 . 
It is recommended to officers to provide health education to pregnant women to increase the knowledge of pregnant women about the dangers of anemia in pregnancy and the importance of consuming $\mathrm{Fe}$ tablets and foods containing iron.

Keywords: characteristics, mother, pregnancy, hemoglobin level

\section{PENDAHULUAN}

Masalah gizi yang banyak terjadi pada ibu hamil adalah anemia gizi, yang merupakan masalah gizi mikro terbesar dan tersulit diatasi di seluruh dunia. World Health Organization (WHO) melaporkan bahwa terdapat $52 \%$ ibu hamil mengalami anemia di negara berkembang. Di Indonesia dilaporkan bahwa dari sekitar 4 juta ibu hamil, separuhnya mengalami anemia gizi dan satu juta lainnya mengalami kekurangan energi kronis (profil kesehatan 2018 dri DepKes, 2018).

Anemia dalam kehamilan adalah kondisi ibu dengan kadar hemoglobin $(\mathrm{Hb})$ $<11$ gr\% pada trimester I dan III sedangkan pada trimester II kadar hemoglobin < 10,5 gr\%. Anemia kehamilan di sebut "potentional danger to mother and child" (potensi membahayakan ibu dan anak), karena itulah anemia memerlukan perhatian serius dari semua pihak yang terkait dalam pelayanan kesehatan (Ari Madi Yanti, Sulistianingsih, \& Keisnawati, 2015). Perempuan hamil membutuhkan 1000 mg besi perhari untuk pertambahan volume darah maternal dan masa sel-sel darah merah fetal. Meskipun tingkat penyerapannya cukup tinggi namun anemia tetap terjadi, umumnya anemia defisiensi besi. Transfer zat besi akan mengalami gangguan akibat defisiensi tersebut. Transfer tersebut diatur oleh plasenta(Pontoh, Mayulu, \& Engka, 2015).

Anemia merupakan suatu kondisi di mana jumlah dan ukuran sel darah merah, atau konsentrasi hemoglobin di bawah batas nilai normal, akibatnya dapat merusak kapasitas darah untuk mengangkut oksigen yang di hantarkan ke seluruh tubuh. Ibu hamil merupakan salah satu kelompok yang berisiko mengalami anemia karena peningkatan volume plasma yang berakibat pengenceran kadar hemoglobin (hb) tanpa perubahan bentuk sel darah merah. Ibu hamil dianggap mengalami anemia bila kadar Hb-nya <11,0 g/dL. (Ngurah Rai, Kawengian, \& Mayulu, 2016)

Kadar Hb ibu hamil terjadi jika produksi sel darah merah meningkat, nilai normal hemoglobin (12 sampai $16 \mathrm{gr} / \mathrm{dl})$ dan nilai normal hematokrit (37\% sampai $47 \%$ ) menurun secara mencolok. Penurunan lebih jelas terlihat selama trimester kedua, saat terjadi ekspansi volume darah yang cepat. Apabila nilai hematokrit turun sampai 35\% atau lebih, wanita dalam keadaan anemia(Tanziha, Utama, \& Rosmiati, 2016)

Wanita hamil sangat rentan terjadi anemia defisiensi besi karena pada kehamilan kebutuhan oksigen lebih tinggi sehingga memicu peningkatan produksi eritropoietin. Akibatnya, volume plasma bertambah dan sel darah merah (eritrosit) meningkat. Namun peningkatan volume plasma terjadi dalam proporsi yang lebih besar jika dibandingkan dengan peningkatan eritrosit sehingga penurunan konsentrasi hemoglobin (Hb) akibat hemodilusi.(Tanziha et al., 2016)

Pengaruh anemia dalam kehamilan dapat berakibat fatal jika tidak segera diatasi diantaranya dapat menyebabkan keguguran, partus prematur,inersia uteri, partus lama, atonia uteri dan menyebabkan perda rahan serta syok. Sedangkan pengaruh anemia terhadap hasil konsepsi diantaranya dapat menyebabkan keguguran, kematian janin dalam kandungan,kematian janin waktu lahir, kematian perinatal tinggi, prematuritas dan cacat bawaan(Ari Madi Yanti et al., 2015). 
Penelitian ini bertujuan untuk melihat hubungan karakteristik dan kadar $\mathrm{Hb}$ ibu hamil trimester di Puskesmas jagir Surabaya.

\section{METODE PENELITIAN}

Jenis penelitian ini ialah analitik deskriptif prospektif dengan desain potong lintang. Penelitian ini dilakukan di Puskesmas Jagir Surabaya pada bulan Maret-Mei 2019. Pemilihan sampel menggunakan metode simple random sampling dengan kriteria inklusinya adalah ibu hamil trimester III yang berkunjung di Puskesmas Jagir Surabaya pada periode penelitian sejumlah 30 orang. Pemeriksaan darah dilakukan untuk pemeriksaan hemoglobin yang dilakukan di Laboratorium Klinik Paramita Surabaya.

\section{HASIL DAN PEMBAHASAN}

A. Karakteristik Responden

Tabel 1 Karakteristik ibu hamil trimester III di Puskesmas Jagir Surabaya

\begin{tabular}{lcc}
\hline Karakteristik & $\mathrm{n}$ & $\%$ \\
\hline Usia & & \\
$\leq 20$ tahun & 2 & 6,6 \\
$21-34$ tahun & 24 & 80 \\
$\geq 35$ tahun & 4 & 13,4 \\
Total & 30 & 100 \\
\hline Paritas & & \\
Primigravida & 10 & 33,3 \\
Multigravida & 20 & 66,7 \\
Total & 30 & 100 \\
\hline Pendidikan & & \\
SMP & 2 & 6,6 \\
SMA & 19 & 63,3 \\
Perguruan & 9 & 30,1 \\
Tinggi & 30 & 100 \\
Total & & \\
Pekerjaan & & \\
Bekerja & 11 & 36,7 \\
Tidak bekerja & 19 & 63,3 \\
Total & 30 & 100
\end{tabular}

Sumber : data primer bulan Maret-Mei 2019

Dari tabel diatas diketahui bahwa sebagian besar responden $(80 \%)$ berada di rentang umur 21-34 tahun dan sebagian kecil $(6,6 \%)$ responden yang berumur $\leq 20$ tahun. Lebih dari setengah $(66,7 \%)$ responden berparitas multigravida dan kurang dari setengah (33,3\%) yang berparitas primigravida. Dapat dilihat juga bahwa lebih dari setengah (63,3\%) responden memiliki pendidikan terakhir di SMA dan hanya sebagian kecil $(6,6 \%)$ responden yang berpendidikan terakhir di SMP sedangkan sisanya hampir setengahnya $(30,1 \%)$ berpendidikan terakhir di Perguruan Tinggi. Lebih dari setengah responden $(63,3 \%)$ bekerja dan hampir setengah $(36,7 \%)$ responden yang tidak bekerja.

B. Kadar Hemoglobin

Tabel 2 Kadar $\mathrm{Hb}$ ibu hamil trimester III di Puskesmas Jagir Surabaya

\begin{tabular}{lll}
\hline $\mathrm{Hb}$ & $\mathrm{n}$ & $\%$ \\
\hline$\leq 11 \mathrm{~g} \%$ & 13 & 43,3 \\
$>11 \mathrm{~g} \%$ & 17 & 56,7 \\
Total & 30 & 100 \\
\hline
\end{tabular}

Sumber : data primer bulan Maret-Mei 2019

Dari tabel diatas dapat dilihat bahwa hampir setengah $(43,3 \%)$ responden yang anemia atau memiliki $\mathrm{Hb} \leq 11 \mathrm{~g} \%$. Serta lebih dari setengah responden $(56,7 \%)$ yang tidak anemia dan memiliki $\mathrm{Hb}>11 \mathrm{~g} \%$.

Tabel 3 Hubungan Karakteristik Responden dan Kadar Hemoglobin pada Ibu Hamil Trimester III di Puskesmas Jagir Surabaya

\begin{tabular}{|c|c|c|c|c|c|c|c|}
\hline \multirow{4}{*}{$\begin{array}{l}\text { Karakte } \\
\text { ristik }\end{array}$} & \multicolumn{4}{|c|}{ Kadar $\mathrm{Hb}$} & \multicolumn{2}{|c|}{ Total } & \multirow{3}{*}{$\begin{array}{c}\underset{p}{p} \\
\text { (val } \\
\text { ue) } \\
< \\
0,05\end{array}$} \\
\hline & \multirow{2}{*}{\multicolumn{2}{|c|}{$\begin{array}{l}\leq 11 \\
\mathrm{~g} \%\end{array}$}} & \multirow{2}{*}{\multicolumn{2}{|c|}{$\begin{array}{c}>11 \\
\mathrm{~g} \%\end{array}$}} & & \multirow{3}{*}{$\%$} & \\
\hline & & & & & $\mathrm{n}$ & & \\
\hline & $\mathrm{n}$ & $\%$ & $\mathrm{n}$ & $\%$ & & & \\
\hline \multirow{4}{*}{$\begin{array}{l}\text { Usia } \\
\leq \quad 20 \\
\text { tahun }\end{array}$} & & & & & & & \multirow{4}{*}{$\begin{array}{c}0,00 \\
1\end{array}$} \\
\hline & 1 & 7, & 1 & 5 & 2 & 6 & \\
\hline & 9 & 6 & 1 & 8 & 2 & 6 & \\
\hline & 3 & & 5 & & 4 & 80 & \\
\hline
\end{tabular}




\begin{tabular}{lrrrrr}
\hline $21-34$ & 69 & 1 & 88 & 4 & 13 \\
tahun &, 2 & &, 4 & &, 4 \\
$\geq \quad 35$ & 23 & & 5, & & \\
tahun &, 2 & & 8 & &
\end{tabular}

\begin{tabular}{lrrrrrrc}
\hline Paritas & & & & & & & 0,00 \\
Primigr & 5 & 38 & 5 & 29 & 1 & 33 & 3 \\
avida & 8 &, 4 & 1 &, 4 & 0 &, 3 & \\
Multigr & & 61 & 2 & 70 & 2 & 67 & \\
avida & &, 5 & &, 6 & 0 &, 7 &
\end{tabular}

\begin{tabular}{lccccccc}
\hline Pendidi & & & & & & & 0,11 \\
kan & 0 & 0 & 2 & 11 & 2 & 6, & \\
SMP & 1 & 76 & 1 &, 7 & 1 & 6 & \\
SMA & 0 &, 9 & 4 & 82 & 9 & 63 & \\
Perguru & 3 & 23 & 1 &, 3 & 9 &, 3 & \\
an & &, 1 & & 6 & & 30 & \\
Tinggi & & & & & &, 1 & \\
& & & & & & & \\
\hline Pekerja & & & & & & & 0,72 \\
an & 2 & 18 & 9 & 47 & 1 & 36 & \\
Bekerja & 9 &, 1 & 1 &, 3 & 1 &, 6 & \\
Tidak & & 81 & 0 & 52 & 1 & 63 & \\
bekerja & &, 2 & &, 7 & 9 &, 7 & \\
& & & & & & &
\end{tabular}

Dari tabel di atas dapat dilihat bahwa lebih dari setengah dari responden $(69,2 \%)$ yang berusia 21-34 tahun memiliki kadar $\mathrm{Hb} \leq 11 \mathrm{~g} \%$, kemudian sebagian besar responden $(88,4 \%)$ yang berusia 21-34 tahun memiliki kadar $\mathrm{Hb}>11 \mathrm{~g} \%$. Dari paritas responden diketahui bahwa lebih dari setengah responden $(70,6 \%)$ memiliki kadar $\mathrm{Hb}>11 \mathrm{~g} \%$. Lalu sebagian besar responden $(82,3 \%)$ yang kadar Hbnya $>11 \mathrm{~g} \%$ berpendidikan terakhir di jenjang SMA. Kemudian lebih dari setengah responden $(81,2 \%)$ yang memiliki kadar $\mathrm{Hb}$ $\leq 11 \mathrm{~g} \%$ adalah ibu rumah tangga atau tidak bekerja.

a. Hubungan antara Usia dengan Kadar $\mathrm{Hb}$ pada Ibu hamil Trimester III di Puskesmas Jagir Surabaya

Sebagian besar $(88,4 \%)$ responden berusia 21-34 tahun memiliki kadar $\mathrm{Hb}$ $>11 \mathrm{~g} \%$. Sebaliknya, pada lebih dari setengah $(69,2 \%)$ responden beruisa 21-34 tahun memiliki kadar $\mathrm{Hb}$ $\leq 11 \mathrm{~g} \%$. Hasil analisis bivariat menunjukkan $\mathrm{p}$ value $0,001 \quad(<0,005)$ hal tersebut menunjukkan terdapat hubungan antara usia dengan kadar $\mathrm{Hb}$ pada ibu hamil trimester III di Puskesmas Jagir Surabaya.

Umur <20 tahun dapat menyebabkan anemia karena pada umur tersebut perkembangan biologis dalam hal ini alat reproduksi belum optimal. Psikis belum matang pada usia $<20$ tahun, hal itu menyebabkan wanita hamil mudah mengala-mi guncangan mental yang mengakibat-kan kurangnya perhatian terhadap pemenuhan kebutuhan zat-zat gizi selama kehamilannya. Kehamilan >35 tahun juga merupakan kehamilan berisiko tinggi. Wanita yang hamil dalam usia yang terlalu tua akan rentan terhadap anemia karena penurunan daya tahan tubuh sehingga mudah terkena berbagai infeksi selama kehamilan. Masa reproduksi yang sehat dan kurang resiko dengan komplikasi kehamilan adalah usia 2035 tahun, sedangkan kehamilan berisiko adalah usia $<20$ dan $>35$ tahun(Oktaviani, Makalew, \& Solang, 2016)

b. Hubungan antara Paritas dengan Kadar $\mathrm{Hb}$ pada Ibu hamil Trimester III di Puskesmas Jagir Surabaya

Lebih dari setengah $(61,5 \%)$ responden multigravida yang memiliki kadar $\mathrm{Hb} \leq 11 \mathrm{~g} \%$ dan kurang dari setengah $(38,4 \%)$ responden baru hamil pertama kali memiliki kadar $\mathrm{Hb}$ $\leq 11 \mathrm{~g} \%$. Hasil analisis bivariat mendapatkan hasil 0,003 $(<0,005)$, hal ini menunjukkan bahwa terdapat hubungan antara paritas dengan kadar Hb pada ibu Hamil Trimester III di Puskesmas Jagir Surabaya.

Semakin banyak jumlah paritas maka akan diikuti dengan meningkatnya kejadian anemia , 
paritas berhubungan dengan terjadinya anemia karena semakin sering wanita melahirkan, lebih besar risiko kehilangan darah dan berdampak pada penurunan kadar hemoglobin. Seorang wanita yang sudah melahirkan lebih dari 2 kali, dan terjadi kehamilan lagi keadaan kesehatannya akan mulai menurun, sering mengalami kurang darah ( anemia). (Wildayani, Yusrawati, \& Ali, 2018)

Ibu yang telah melahirkan lebih dari 3 kali berisiko mengalami komplikasi serius seperti perdarahan, hal ini dipengaruhi keadaan anemi selama kehamilan. Disamping itu pendarahan yang terjadi mengakibatkan ibu banyak kehilangan haemoglobin dan cadangan zat besi menurun sehingga kehamilan berikutnya menjadi lebih berisiko untuk mengalami anemia lagi.(Herawati \& Astuti, 2010)

c. Hubungan antara Pendidikan dengan Kadar Hb pada Ibu Hamil Trimester III di Puskesmas Jagir Surabaya

Sebagian besar $(82,3 \%)$ responden yang berpendidikan terakhir di Sekolah Menengah Atas memiliki kadar $\mathrm{Hb}$ $>11 \mathrm{~g} \%$ dan tidak ada $(0 \%)$ responden berpendidikan terakhir di Sekolah Menengah Pertama yang memiliki kadar $\mathrm{Hb} \leq 11 \mathrm{~g} \%$. Hasil analisis bivariat mendapatkan hasil 0,11 $(<0,005)$ yang artinya menunjukkan bahwa tidak ada hubungan antara pendidikan dan kadar $\mathrm{Hb}$ pada ibu hamil trimester III di Puskesmas Jagir Surabaya.

Pada kelompok berpendidikan rendah pada umumnya memiliki akses pengetahuan tentang anemia yang kurang, kurang memahami akibat yang ditimbulkan dari anemia, kurang dapat memilih bahan makanan yang bergizi khususnya yang terdapat kandungan zat besi serta kurangnya pemanfaatan layanan kesehatan masyarakat yang tersedia sehingga dapat mempengaruhi kadar $\mathrm{Hb}$. Asupan gizi merupakan faktor yang mempengaruhi anemia pada ibu hamil. Oleh karena itu asupan gizi menjadi sangat penting. Seperti penelitian yang dilakukan Abriha A bahwa prevalensi anemia pada ibu hamil secara keseluruhan yang dilakukannya adalah 19,7\% dengan konsumsi daging yang sangat kurang.(Ari Madi Yanti et al., 2015)

Terdapat hubungan yang bermakna dengan hasil penelitian sebagian besar ibu hamil berpendidikan menengah dan tidak mengalami anemia sebesar $77,2 \% .24$ Tingkat pendidikan memiliki peranan yang sangat penting untuk mendapatkan pekerjaan. Tingkat pendidikan responden juga sangat mempengaruhi besarnya pendapatan responden. Semakin tinggi pendidikan seseorang maka pekerjaan dan pendapatannya semakin layak dan meningkat hal ini juga berpengaruh terhadap pendapatan dari keluarga. Jika dikaitkan dengan kesehatan, pendidikan dengan kesehatan memiliki pengaruh yang berkaitan.(Tanziha et al., 2016)

d. Hubungan antara Pekerjaan dan kadar $\mathrm{Hb}$ pad Ibu Hamil Trimester III di Puskesmas Jagir Surabaya

$$
\text { Hampir setengah (47,3\%) }
$$
responden yang bekerja memiliki kadar $\mathrm{Hb}>11 \mathrm{~g} \%$. Sedangkan sebanyak lebih dari setengah $(42,7 \%)$ responden yang tidak bekerja memiliki kadar $\mathrm{Hb}$ $\leq 11 \mathrm{~g} \%$. Hasil analisis bivariat mendapatkan hasil 0,72 yang artinya menunjukkan bahwa pekerjaan tidak berhubungan dengan kadar $\mathrm{Hb}$ pada ibu hamil trimester III di Puskesmas Jagir Surabaya.

Berbeda dengan penelitian Ani dkk yang menyatakan bahwa responden yang tidak bekerja cenderung memiliki status sosial 
ekonomi yang lebih rendah dan mereka harus melakukan kerja keras selama kehamilan untuk mencukupi kebutuhannya. Hal ini menyebabkan kebutuhan nutrisi tidak tercukupi, jarak kelahiran pendek, perawatan antenatal yang tidak memadai.19 Ibu hamil dengan status pekerjaan tidak bekerja hanya sebagai ibu rumah tangga merupakan faktor resiko terjadinya anemia karena sebagian besar pendapatannya bergantung pada penghasilan suami untuk memenuhi kebutuhannya, sebagian ibu rumah tangga tersebut merupakan pada tingkat sosial ekonomi rendah. Anemia ditemukan pada pendapatan bulanannya rendah. (Ani, Bakta, Suryadhi, \& Bagiada, 2007)

\section{SIMPULAN}

Terdapat hubungan antara usia dengan kadar $\mathrm{Hb}$ pada ibu hamil trimester III di Puskesmas jagir Surabaya. Terdapat hubungan antara paritas dengan kadar $\mathrm{Hb}$ pada ibu hamil trimester III di Puskesmas Jagir Surabaya. Tidak terdapat hubungan antara pendidikan dan kadar $\mathrm{Hb}$ pada ibu hamil trimester III di Puskesmas Jagir Surabaya. Serta tidak terdapat hubungan antara pekerjaan dan kadar $\mathrm{Hb}$ pada ibu hamil trimester III di Puskesmas Jagir Surabaya.

\section{SARAN}

Memberikan pendidikan kesehatan pada ibu hamil untuk meningkatkan pengetahuan ibu hamil tentang bahaya anemia dalam kehamilan dan pentingnya mengkonsumsi tablet fe dan makanan yang mengandung zat besi

\section{UCAPAN TERIMA KASIH}

Terima kasih kami ucapkan kepada Puskesmas Jagir Surabaya, Laboratorium Pramita Surabaya dan Universitas
Nahdlatul Ulama Surabaya serta para responden yang telah banyak membantu pelaksanaan penelitian ini

\section{REFERENSI}

Ani, L. S., Bakta, I. M., Suryadhi, I. N. T., \& Bagiada, I. N. A. (2007). Pengaruh Pemberian Tablet Besi Terhadap Kada Feritin Serum dan Hemoglobin pada Wanita Pra-hamil dengan Anemia Defisiensi Besi Derajat Ringan di Bali, $1-11$.

Ari Madi Yanti, D., Sulistianingsih, A., \& Keisnawati. (2015). Faktor-Faktor Terjadinya Anemia pada Ibu Primigravida di Wilayah Kerja Puskesmas Pringsewu Lampung. Jurnal Keperawatan, 6(2), 79-87. Retrieved from http://download.portalgaruda.org/artic le.php?article $=424747 \& \mathrm{val}=278 \&$ titl $\mathrm{e}=$ FAKTOR-FAKTOR TERJADINYA ANEMIA PADA IBU PRIMIGRAVIDA DI WILAYAH KERJA PUSKESMAS PRINGSEWU LAMPUNG

Herawati, C., \& Astuti, S. (2010). FaktorFaktor yang Berhubungan dengan Anemia Gizi pada Ibu Hamil di Puskesmas Jalaksana Kuningan Tahun 2010. Jurnal Kesehatan Kartika, 5158. Retrieved from http://www.stikesayani.ac.id/publikas i/ejournal/filesx/2010/201012/201012007.pdf

Ngurah Rai, I. G. B., Kawengian, S. E. S., \& Mayulu, N. (2016). Analisis faktorfaktor yang berhubungan dengan kadar hemoglobin pada ibu hamil. Jurnal E-Biomedik, 4(2). https://doi.org/10.35790/ebm.4.2.201 6.14627

Oktaviani, I., Makalew, L., \& Solang, S. (2016). Profil Haemoglobin Pada Ibu Hamil Dilihat Dari Beberapa Faktor 
Pendukung. Jurnal Ilmiah Bidan, 4(1), 90985.

Pontoh, S., Mayulu, N., \& Engka, J. N. (2015). Hubungan Kadar Ferritin Dan Asupan Protein Pada Ibu Hamil Trimester Ii-Iii Di Kabupaten Bolaang Mongondow Utara. Jurnal EBiomedik, 3(3). https://doi.org/10.35790/ebm.3.3.201 5.10159

Profil kesehatan 2018 dri DepKes. (2018).

Tanziha, I., Utama, L. J., \& Rosmiati, R.
(2016). Faktor Risiko Anemia Ibu Hamil Di Indonesia, 11(2), 143-152. https://doi.org/10.25182/jgp.2016.11. $2 . \% \mathrm{p}$

Wildayani, D., Yusrawati, \& Ali, H. (2018). Pengaruh Pemberian Tablet Zink dan Besi terhadap Kadar Hemoglobin dan Feritin pada Ibu Hamil Anemia Defisiensi Besi. Jurnal Kesehatan Andalas, 7(Supplement 4), 1-5. Retrieved from http://jurnal.fk.unand.ac.id/index.php/ jka/article/view/913 